\title{
Article \\ Corporate Cash Holdings and National Culture: Evidence from the Middle East and North Africa Region
}

\author{
Sherif El-Halaby ${ }^{1,2}$, Hosam Abdelrasheed ${ }^{1,3}$ and Khaled Hussainey $4, *(\mathbb{D}$ \\ 1 Faculty of Business Studies, Arab Open University, Kuwait Branch, Al-Ardia Industrial Area, P.O. Box 830, \\ Al-Ardia 92400, Kuwait; sismail@aoukwt.onmicrosoft.com (S.E.-H.); \\ habdelrasheed@aoukwt.onmicrosoft.com (H.A.) \\ 2 Business School, Modern Science and Arts (MSA) University, Cairo 12566, Egypt \\ 3 Faculty of Business, Ain Shams University, Cairo 11566, Egypt \\ 4 Faculty of Business and Law, University of Portsmouth, Portsmouth PO1 3QL, UK \\ * Correspondence: khaled.hussainey@port.ac.uk; Tel.: +44-772-719-0105
}

Citation: El-Halaby, Sherif, Hosam Abdelrasheed, and Khaled Hussainey. 2021. Corporate Cash Holdings and National Culture: Evidence from the Middle East and North Africa Region. Journal of Risk and Financial Management 14: 475. https:// doi.org/10.3390/jrfm14100475

Academic Editor: Ştefan

Cristian Gherghina

Received: 10 August 2021

Accepted: 27 September 2021

Published: 8 October 2021

Publisher's Note: MDPI stays neutral with regard to jurisdictional claims in published maps and institutional affiliations.

Copyright: (C) 2021 by the authors Licensee MDPI, Basel, Switzerland. This article is an open access article distributed under the terms and conditions of the Creative Commons Attribution (CC BY) license (https:// creativecommons.org/licenses/by/ $4.0 /)$
Abstract: This paper investigates to what extent cultural dimensions, based on Hofstede's model, can clarify differences in cash holding levels. The sample includes 395 banks across 19 countries in the Middle East and North Africa region over a period of 16 years (1999-2014). The findings indicate that when uncertainty avoidance and masculinity decrease, cash holdings increase, whereas when power distance, long-term orientation, and individualism increase, the cash holdings increase correspondingly. Based on robustness analysis, the results remain unaffected even after controlling corporate and macroeconomic characteristics related to inflation, corruption, and the exchange rate system. Further analysis shows insignificant differences between Islamic and non-Islamic banks regarding the influence of culture over cash holdings. This study contributes to the literature regarding the impact of culture on corporate cash holdings based on a unique and different context, through examining this relationship in financial institutions located in the Middle East and North Africa region.

Keywords: cash holdings; culture; Middle East and North Africa region

\section{Introduction}

Several operational, financial, and investment decisions have to be made by corporate management. The amount of cash held by the company is considered one of the most important factors that should be taken into consideration when making such decisions. In recent years, corporate cash holding levels are witnessing a continuous increase all over the world. According to S\&P Global, cash and total liquid assets for nonfinancial companies in the United States reached USD 2.1 trillion at the end of 2017, while according to Moody's, nonfinancial companies in Africa, the Middle East, and Europe recorded USD 1 trillion in corporate cash for the second consecutive year. Additionally, according to Orbis by Bureau van Dijk, cash of the top 25 global public companies in the world reached USD 1.18 trillion in 2018 compared with USD 97 trillion in 2017. This USD 1.18 trillion represent $20 \%$ of the total assets of these companies (Obiols 2018), even though various studies show that there is a huge difference between companies and countries regarding cash holding levels and the percentage of cash to total assets (e.g., Bates et al. 2009; Chen et al. 2015).

In recent years, the effect of national culture on firms' financial decisions has acquired a lot of traction. The motivation behind this lies in the fact that culture plays a fundamental role in influencing corporate visions and principles and eventually its decisions. Hence, based on Nash and Patel (2019), national culture influences business financial decisions as an informal instinct. The difference in national cultures is considered a possible motive for the heterogeneity in cross-national decision making as holding cash. Despite the large number of empirical studies that examined the determinants of cash holdings 
(e.g., Seifert and Gonenc 2018; Al-Najjar and Clark 2017), the influence of culture on cash holdings has received little attention as few studies have examined this relationship (e.g., Fernandes and Gonenc 2016; Chang and Noorbakhsh 2009). Additionally, most empirical studies that examined this relationship have excluded financial firms and used a sample of non-financial firms. Furthermore, to the best of our knowledge, the effect of culture on cash holdings over the financial institutions (banks) in the Middle East and North Africa (MENA) region has not been studied yet. Consequently, the main objective of this paper is to examine to what extent culture may affects cash holding levels of banks in MENA countries.

This paper provides a number of important contributions to the existing literature on cash holding as well as consequences of culture. First, this study is one of the first empirical studies that examines the effect of national culture on cash holding in financial institutions, while all the previous studies were limited to non-financial institutions (e.g., Chang and Noorbakhsh 2009; Ramírez and Tadesse 2009). Second, this study complements the existing literature on cash holding by examining the effect that national culture could have on banks' cash holding in MENA countries. The studies that examine cash holding in MENA courtiers, in contrast to the studies that examine cash holding in the United States and Europe, are very rare. Third, this study takes the investigation much further by studying the differences (if any) between Islamic and non-Islamic banks in terms of the impact of culture on their cash holding levels. Fourth, contrary to the majority of studies that utilized only one or two of Hofstede's cultural dimensions (e.g., Chen et al. 2015; Fernandes and Gonenc 2016; Tran 2020), the researchers include in their analysis the five Hofstede's cultural dimensions in an attempt to reach a thorough understanding of their effects on cash holdings. Finally, this study uses a distinctive updated dataset for the period 1999 to 2014, which offers us with the biggest firm-year observation sample for MENA countries.

The findings show a negative relationship between cash holding level and masculinity and uncertainty avoidance (UA), while demonstrating a positive relationship between cash holdings level and individualism; power distance (PD) and long-term orientation (LTO). Depending on the robustness analysis, the previous results remain unchanged after controlling for corporate characteristics (stock market listing; return on assets (ROA); size and leverage) and macroeconomic characteristics (inflation; corruption and exchange rate). This paper is structured as follows. Section 1 is an introduction. Section 2 shows the literature review and hypotheses development. Section 3 illustrates the research methodology. Section 4 presents the empirical analysis in addition to robustness tests. Finally, Section 5 provides concluding remarks.

\section{Literature Review and Hypotheses Development}

\subsection{Corporate Cash Holdings and National Culture}

The existing literature on corporate cash holdings reveals that there are a number of theories that have been advanced to explain the motives for holding cash by companies. The most common theories used are: the trade-off theory developed by Myers $(1977,1984)$, the pecking order theory proposed by Myers and Majluf (1984), and agency theory developed by Jensen (1986).

Trade-off theory: This theory is based on a postulate that there is an optimal level of cash holding that can be achieved by considering the trade-off between the marginal benefits and marginal costs of holding cash (Opler et al. 1999). According to Ferreira and Vilela (2004), there are several advantages for holding cash. First, reducing the probability of financial distress because cash holding acts as a safety reserve to face unexpected losses or external fund-raising constraints. Second, allowing optimal investment policy to be pursued even when financial constraints are met. Otherwise, the firm would be forced to abandon investment projects with a positive net present value due to external funding constraints. Finally, minimizing the costs of raising external funds or liquidating existing assets by acting as a buffer between the firm sources and uses of funds. 
Meanwhile, the main cost of holding cash is the opportunity cost of the capital that has been invested in liquid assets that usually yields low returns. Opler et al. (1999) state that according to Keynes (1936), companies are holding cash for two principal motives: the transaction cost motive and the precautionary motive. The first motive implies that companies are holding cash to save transaction costs needed to raise funds. The precaution motive means that companies hold excess cash to guarantee their continuous ability to invest in profitable project even when they are very short in cash, compared with investments needed, also when outside funds are expensive. Therefore, holding cash by firms may be considered more beneficial in order to lessen costs of financial distress.

Pecking order theory: According to the pecking order theory, which is also referred to as financial hierarchy theory, cash holding levels are not determined according to the trade-off between cash holding's benefits and costs; rather, they are based on financing decisions. Companies usually resort to their internal financing sources first (Retained Earnings) to fund investment, because the internal financing sources are less costly than external financing sources. This means that companies are usually following a pecking order of financing. This order starts with internal sources then debt financing then equity financing. Myers (1984) and Myers and Majluf (1984) propose that companies are following this pecking order so as to lower costs arising from information asymmetry between firms and external investors, and external funding will only be used by companies, following the exhaustion of internal funding. Myers (1984) suggests that firms favor external funding by debt compared with equity issuance, since debt has lower information costs than equity financing. Under the pecking order theory, there is no optimal level of cash holdings and cash is used as a buffer between retained earnings and investment needs.

Agency Theory: Separating ownership from management resulted in an agency relationship between Agent (Management) and Principal (shareholders). Managers should act on behalf of shareholders and invest in projects that maximize shareholders' wealth. Unfortunately, the objectives of managers are not always aligned with the objectives of shareholders, resulting in agency problems. Under the free cash flow theory of Jensen (1986), which is also called agency theory, managers tend to hold large cash reserves to increase their discretionary powers over the company's investment decisions. Additionally, these cash reserves are not exposed to the capital markets scrutiny, as is the case when companies depend on external sources of financing, and they may use such reserves to boost their advantages and rewards to the detriment of shareholders if these reserves invested in value-reducing investment projects from the shareholders' point of view.

Several studies examine the effect of culture on different aspects inside and outside corporations. For example, Tabellini (2010) studied the effect of culture on economic development and reports that, there are two sets of cultural traits (trust, respect, control and obedience) which have favorable effect on economic development. Tabellini argues that these cultural traits can influence economic development either directly or indirectly. Guiso et al. (2006) studied to what extent the culture can affect economic behavior and report that "cultural hypotheses can be rigorously tested and are economically important for fundamental economic issues like national rates of saving" (p. 25). Furthermore, Gorodnichenko and Roland (2017) argued that innovation and growth are positively influenced by the individualistic culture. They found a strong relationship between cultural traits and economic results.

Kwok and Tadesse (2006) studied the effect of culture on financial systems used in countries. They argue that the degree of risk tolerance prevailed in a country has a direct effect on the choice of which financial system usually used in that country. Therefore, in countries with high uncertainty avoidance, bank-based financial system is preferable whereas market-based system is more preferable in countries with low uncertainty avoidance. In addition, several studies investigate the relationship between culture and corporate structure. Zheng et al. (2012) investigated this relationship using Hofstede's model across firms from 40 countries. Their results support the notion that differences between countries 
regarding the corporate debt maturity structure can be attributed to differences in culture prevailed in these countries.

Fauver and McDonald (2015) investigated the interaction of individualism and risk aversion, with capital structure and corporate governance across G20 countries. They found that high levels of individualism are associated with a high level of debt utilization and lower level of cost of capital. Additionally, strong corporate governance lessens the effect of individualism and risk aversion. The effect of culture on capital structure is stronger in developed than in emerging countries. Haq et al. (2018) examined national culture effect on bank leverage and found that a high level of individualism is associated with a high level of leverage. On the contrary, high levels of UA, PD, and LTO are associated with low levels of leverage, whereas Orlova and Harper (2021) explored the influence of national culture on leverage speed of adjustment, and found that culture has a significant impact on the degree to which firms deviate from their target debt level as well as the speed of adjustment (SOA) of leverage.

Other studies have documented that culture influences corporate risk-taking. Li et al. (2013) found that a high level of individualism is associated with a high level of corporate risktaking, while uncertainty avoidance has the opposite effect. Diez-Esteban et al. (2019) analyzed the effect of both culture and religion on corporate risk-taking. Their results were similar to Li et al. (2013). They observed that differences in religion background leads to differences on corporate risk-taking. Li et al. (2021) explored how Buddhism culture affects cash holding. Additionally, Chen et al. (2020) studied the Confucianism culture impacts on cash holdings with data on China. Another set of studies dealt with the effects that culture have on dividend policies. Zheng and Ashraf (2014) examined the relations between culture and dividend policies in different banks. They found that banks operating in high UA, high LTO, and low masculinity countries pay a lower amount of dividends and are less likely to pay dividends.

Byrne and O'Connor (2017) studied the interaction between culture and creditor rights and how this interaction affects the dividend pay-out policy of companies. Their results show that culture in addition to the strength of creditors' rights plays an important part in influencing the dividend pay-out policy of the corporation. Other studies have documented the impact of culture on consumption patterns of life insurance products (Chui and Kwok 2008), multiple aspects of cross-border mergers (Ahern et al. 2015), corporate misconduct (Liu 2016), international underpricing of initial public offerings (Chourou et al. 2018), long-term takeover performance (Breuer et al. 2018), and trading volume, volatility, and momentum profits (Chui et al. 2010). Kashefi-Pour et al. (2020) studied the relationship between culture and investment-cash flow sensitivity. Their results show that some of the cultural dimensions, UA, PD, and masculinity, have a strengthening impact on the relationship between cash flow and investment. Achim et al. (2019) studied the impact of culture, religion, and happiness variables on the size of the shadow economy. Their results show that some of the cultural variables, collectivism, femininity, a short-term orientation, restraint, and religiosity increase the size of the shadow economy, while greater happiness reduces it.

Corporate cash levels have been managed close to specific target levels and were thought to be rarely influenced by other firm-specific variables. However, differences in cash levels across firms can be observed all over the world (Prenker and Kück 2009). Recently, scholars have paid huge attention to the causes and consequences of corporate cash holdings. Determinants of cash holdings have been the focal point in a large number of studies and several empirical studies have examined these determinants. Corporate governance is considered one of the main factors that affect the cash holdings levels in firms and a large bulk of literature was devoted to examining the validity of this relationship. Dittmar et al. (2003) studied the relationship between corporate cash holdings and corporate governance in different countries. The results suggest that the higher level of protection, the lower level of cash holding. Ferreira and Vilela (2004) obtained the same findings. 
Ozkan and Ozkan (2004) investigated corporate cash holdings determinants in companies from the United Kingdom. The results suggest that corporate ownership structure, as one of the corporate governance characteristics, is considered one of the key determinants of cash holding. Harford et al. (2008) investigated the relationship between cash holdings and corporate governance in the United States of America and concluded that companies that have weak corporate governance structure have small cash reserves. Their findings contradict those of Chang and Noorbakhsh (2006).

According to Seifert and Gonenc (2016), corporate cash holdings have a negative relation with the interactive term of strong creditor rights as well as strong country governance. Al-Najjar and Clark (2017) investigated the effect of internal and external corporate governance mechanisms on cash holdings in MENA countries. Their results show that in regard to internal mechanisms, the association between board size and cash holding is negative. In regard to external mechanisms, the results are not conclusive. They find that the higher the level of international standards of securities law and bank supervision applied in a country, the lower the level of cash holding. Additionally, the higher the level of fiscal transparency and good governance practices applied in a country, the higher the level of cash holdings. Finally, they reveal that firm size, profitability, and capital structure are major drivers of cash holdings.

Seifert and Gonenc (2018) studied the impacts of country-level governance and firmlevel governance on cash holdings. They found that the higher the country-level governance and firm-level governance, the lower the level of cash holdings. These findings confirm the great importance of shareholder protection factor in determining cash holding levels. Corporate governance was not the only firm level variable that attracts the attention of researchers. Many studies have examined the relation between different firm level variables and corporate cash holdings in order to identify which variable has the greatest effect on cash holding levels. Dividend policy has attracted the attention of many scholars such as Al-Najjar (2013); Al-Najjar and Belghitar (2011); and Kim et al. (2011). These studies have found that the relation between dividends and cash holdings levels is negative. Studies of Opler et al. (1999); Ferreira and Vilela (2004); Al-Najjar and Belghitar (2011); and Ozkan and Ozkan (2004) show significant evidence for the negative impact of leverage on cash holdings levels. Le et al. (2018) re-examined the determinants of cash holding in UK listed firms and found that firm size, leverage, cash flow, cash flow volatility, and investment opportunity all have an impact on managers' cash holding behavior. A recent study by Haj-Salem and Hussainey (2021) shows that there is a negative relationship between corporate risk disclosure and corporate cash holdings. Another recent study by Ozkan et al. (2021) examined the relation between IFRS adoption and cash holdings in ten Arab nations in the Middle East and North Africa region. Their results reveal that there is a negative relationship between IFRS adoption and cash holdings.

Country-level variables, as determinants of cash holding levels, also attract the attention of many researchers. Various studies have examined the relation between different country-level variables and cash holdings. Dittmar et al. (2003) measure whether a country's legal system affects cash holdings and concluded "firms in common law countries hold less cash than those located in civil law countries" (p. 115). Pinkowitz et al. (2003) found a positive link between corporate cash holding and corruption and they furthermore showed a negative relationship between corporate cash holding and inflation. Foley et al. (2007) showed that firms facing higher repatriation taxes hold higher levels of cash, hold this cash abroad, and hold this cash in affiliates that trigger high tax costs when repatriating earnings.

Indeed, many studies on cash holdings have focused on firm characteristics and/or country characteristics as determinants of cash holding. However, a recent stream of research is trying to shed light on the impact of managerial characteristics on cash holdings. Tran et al. (2021) examined the impacts of managerial optimism on corporate cash holdings. Their study revealed that that firms managed by optimistic managers had higher cash holdings than firms managed by non-optimistic managers. An opposite result has been obtained by Deshmukh et al. (2021), as they demonstrated that that firms managed by 
optimistic CEOs hold cash balances that are, on average, 24 percent lower than those in firms managed by non-optimistic CEOs. Zhou et al. (2021) studied the relationship between organizational identification (which refers to the degree to which employees define themselves as a member of the organization and to what extent they experience a sense of oneness with it, its values, brand, methods) and corporate cash holdings. Their results showed that there is a negative relationship between organizational identification and corporate cash holdings, and this negative association is more pronounced at higher levels of financial development and at lower levels of economic uncertainty.

Studies that investigate the association between national culture and corporate cash holdings are relatively rare in the literature. Chang and Noorbakhsh (2009) studied the impact of culture on cash holding. They argued that culture has an impact on the cash holding behavior of managers beyond the corporate governance impact and the impact of developments in the financial markets. They found that companies tend to hold more cash in countries high in UA, masculinity, and LTO. Similarly, Ramírez and Tadesse (2009) investigated the impact of both culture and multi-nationality on corporate cash holdings across different companies in different countries. They argued that cultural factors and firm multi-nationality influence cash holdings. The results of the study supported their arguments. First, companies tend to hold more cash in countries high in UA. Second, multinational companies hold higher levels of cash than their national companies do. These findings are consistent with Foley et al. (2007).

Additional studies by Chen et al. (2015) have explored whether national culture clarifies the differences in corporate cash holding around the globe, and whether there is an association between the individualism-collectivism dimension within the United States of America and cash holdings. They employ individualism and uncertainty avoidance from Hofstede's cultural dimensions. They also employ Vandello and Cohen (1999) individualism-collectivism dimension. Their results indicate that, there is a negative association between individualism and cash holding, whereas the association between uncertainty avoidance and cash holding is positive. These findings are consistent with Ramírez and Tadesse (2009). These results prove that cultural factors can explain cash holdings differences between companies around the globe and prove that there is an association between cash holdings and Vandello and Cohen dimension.

Fernandes and Gonenc (2016) investigated multinational companies to figure out if geographical diversity and industrial diversity has an impact on cash holding levels. Their results indicate that the relationship between cash holding and both geographical diversity and industrial diversity is negative. In addition, the results indicate that geographical diversity is more important than industrial diversity. They furthermore found that the effect of diversification on cash holdings is moderated by various country characteristics. Two of Hofstede's cultural dimensions, UA and individualism, were among these countrylevel characteristics. Ucar (2018) found that firms located in areas with a strong creative culture face more risk, invest more, and grow faster. In accordance with the precautionary motive, these firms also accumulate more cash. A recent study by Tran (2020) investigated whether the global financial crisis affected the relationship between one of Hofstede's cultural dimensions, which is UA, and cash holdings. The results of the study reveal that the influence of UA on cash holdings is larger in the post-crisis period.

Following Chang and Noorbakhsh (2009), through posting different hypotheses, this paper argues that the determinants of cash holding in banks cannot be limited to different firm-level variables that were extensively investigated in the literature. Besides firmlevel variables, the variables related to culture also play a major role in explaining cash holdings behavior in banks. Indeed, within a diversified group of countries included in the sample, this paper argues that, regarding the cash holding behavior, the cultural variables have more explanatory power than the explanatory power of company-level variables. Following the majority of studies in the literature regarding culture, this paper uses the cultural dimensions of Hofstede to explore whether cultural factors would influence bank cash holdings in 19 different countries located in the MENA region beyond the effects of 
company-level variables. In contrast to the majority of studies that utilized only one or two cultural dimensions of Hofstede, this paper includes five of Hofstede's cultural dimensions in the analysis in order to investigate their effects on cash holdings.

\subsection{Hypotheses Development}

Hofstede's model has been adopted extensively in accounting literature (e.g., Beugelsdijk and Frijns 2010; Hope et al. 2008). This study examines the five dimensions of Hofstede to measure their impact on cash holdings as follows:

Individualism, according to Hofstede (2001), reflects the degree to which people focus on their internal attributes, such as their own abilities, to differentiate themselves from others. The distinction between individualistic and collectivistic cultures pertains to the degree to which people in a country tend to have an independent rather than an interdependent self-construct (Chui et al. 2010). According to Van Den Steen (2004), people in individualistic countries certainly have a tendency to overestimate their own abilities, and they tend to be overly optimistic about the high accuracy of their projections. Orlova et al. (2017) anticipated that the high level of individualism is associated with a high level of cash holding, contrary to UA which is negatively associated with cash holding. This paper hypothesizes that managers' use of cash differs between collectivistic and individualistic cultures, and directors in countries with a high level of individualism tend to hold more cash as they are more confident about the financial performance of their companies. Therefore, this paper, following Orlova et al. (2017), assumes that individualism has a positive correlation with corporate cash holdings.

The power distance dimension expresses how much less powerful members of a society accept and expect unequal power distribution (Hofstede 1980, 2001). People in high power distance societies accept a hierarchical order in which everybody has a place and no justification is required for power inequalities (Mittal and Elias 2016). Across countries with a high level of PD, people in power can change the rules to suit their own interests and benefits, particularly in regard to cash. This paper assumes that managers in countries with a high level of PD keep more cash because they do not need to justify their decisions as they have complete control over their businesses.

The uncertainty avoidance refers to the capability of a society to manage and alleviate uncertainties and complications. The country-level UA developed by Hofstede (2001) assesses society's tolerance for uncertainty and ambiguity. According to Hofstede, a low UA indicates a society that is less rule-oriented, more willing to accept change, and takes more and larger risks. Countries with a low level of UA are more tolerant of a changing environment. The higher the value of UA, the less willing directors are to take risks and the more eager they are to keep more liquid assets in exchange for risk hedging. Companies in countries with a high level of UA keep more cash as a way to hedge against unfavorable natural conditions. (Chang and Noorbakhsh 2009). Directors from high UA cultures are less accepting of uncertainty associated with upcoming cash-flows generated by companies, and thus keep more cash to compensate for bearing this uncertainty. As a result, UA culture is positively related to cash holdings (e.g., Chen et al. 2015; Kanagaretnam et al. 2014; Arosa et al. 2014). Therefore, this paper assumes that uncertainty avoidance has a positive correlation with corporate cash holdings.

Masculinity is concerned with person's level of self-confidence and willpower in a given culture, and it is entirely intended to refer to male dominance. Individuals with such morals engage in competitive behaviors, indicating a proclivity for greater success. Masculinity refers to the importance of sex (men versus women) in the distribution of social characters. Directors place a high value on effective performance in highly masculine societies because it provides them with additional social gratitude as well as personal appreciation (Zhang et al. 2016). It is assumed that directors in masculine culture are more concerned with performance. When directors face novel investment opportunities, they conduct their own research and make their own assumptions. The risks taken may be 
rewarded with a massive payout. As a result, these companies are more likely to keep enough cash on hand to capitalize on opportunities as they arise.

According to Hofstede (2001), Long Term Orientation (LTO) stands for the fostering of virtues oriented towards future rewards, particularly perseverance and thrift. Its opposite pole, Short Term Orientation, stands for the fostering of virtues related to the past and present, particularly, respect for tradition, preservation of 'face' and fulfilling social obligations. Patience, persistence, thrift, and self-reliance are perceived as personal virtues by corporate managers in countries with higher LTO index scores. Investment opportunities are generally assessed based on their ability to generate long-term value. Investors prefer long-term profitability and value enhancement over short-term rates of return. As a result, managers are not constantly under pressure from shareholders to produce short-term positive returns (Chang and Noorbakhsh 2009). Furthermore, Newman and Nollen (1996) demonstrate that providing long-term employment is considered as one of the management practices that is consistent with a long-term cultural orientation. As a result, businesses must maintain larger cash and liquid asset balances in order to provide long-term job security to their employees. Therefore, this paper assumes that long term orientation has a positive correlation with corporate cash holdings.

Based on the preceding discussion, the following hypotheses are developed in this paper:

Hypothesis 1. There is a positive association between high uncertainty avoidance and cash holding.

Hypothesis 2. There is a positive association between high masculinity and cash holding.

Hypothesis 3. There is a positive association between high individualism and cash holding.

Hypothesis 4. There is a positive association between high power distance and cash holding.

Hypothesis 5. There is a positive association between high long-term orientation and cash holding.

\section{Methodology}

\subsection{Sample and Data Collection}

The data for this study were gathered from a variety of sources in order to conduct the tests for the aforementioned hypotheses. Definition: sources and measurement of each category of the variable are summarized in Table 1. In constructing the variables, this paper follows models tested by Chen et al. (2015); Bates et al. (2009); and Pinkowitz et al. (2003). The main dependent variable is the ratio of cash holding, which is measured as the amounts of cash and short-term investments divided by the amounts of total assets. The independent variable is culture, based on Hofstede's five dimensions, which are obtained from Hofstede's psychological survey of IBM worker values. The scores of Hofstede's cultural dimensions are obtained from the Hofstede insights website.

This paper obtains the financial data for the sample from different sources, which are bank scope, data stream, and annual reports. Non-financial firms are not included in the sample since their capital needs and regulation may differ from those in banks. Data for inflation rates and corruption for the nominated countries are taken from the World Bank's database. The final data set includes annual time series panels and cross-sectional financial data for over 6500 firm-year observations. Based on data availability of annual reports and access to databases, this study starts with a preliminary sample of 500 banks from 22 countries, and after applying several filtrations, the final sample included 395 banks from 19 different countries in the MENA region for 16 years between 1999 and 2014. Selecting banks for this study is supported by Bitar et al. (2020), who stated that bank regulations and performance are influenced by culture. The sample includes countries located in the MENA region which are: Algeria; Bahrain; Egypt; Iran; Iraq; Israel; Jordan; Kuwait; Lebanon; Libya; Morocco; Oman; Palestine; Qatar; Saudi Arabia; Syria; Tunisia; United Arab Emirates; and Yemen. 


\subsection{Variables and Research Models}

This paper investigates whether Hofstede's cultural dimensions can be used as an explanatory variables of cash holdings of banks in MENA region. Cash holding percentage in this study is measured through dividing cash and cash equivalents over total assets (current and non-current assets). As a robustness analysis and in conformance with Dittmar et al. (2003) and Opler et al. (1999), this study uses an additional method for calculating cash holdings, which is based on the natural logarithm of cash holdings. The culture variable is the most important explanatory variable in this study, which has five dimensions: masculinity; PD; UA; individualism, and LTO. Furthermore, the most significant financial variables used in previous studies of cash holdings (e.g., Harford et al. 2008; Dittmar and Mahrt-Smith 2007) are included as control variables in the regression models. The following firm characteristics are added as control variables in this study: profitability, leverage, size, bank type, and listing in the stock market. To capture a firm's financial performance, the study uses the accounting measure: return on assets (ROA). This measure has been used in several studies concerned with the banking industry. (e.g., Patricia and Garcia-Lacalle 2018; Tasawar and Haniffa 2017; Zouari and Taktak 2014; Mondal and Ghosh 2012). According to the trade-off theory, companies with a high leverage ratio face greater risk and are more likely to face insolvency. As a result, high-leverage corporations keep more cash on hand to avoid situations such as this. The pecking order theory, on the other hand, hypothesizes a negative relationship because leverage can be used as a substitute for issuing debt. As a result, debt can serve as a substitute for cash, and companies with more liquid assets can easily convert to cash. Several studies support a negative impact of leverage on cash holdings (e.g., Shabbir et al. 2016; Uyar and Kuzey 2014).

Regarding company size, the trade-off theory suggests that big corporations are more profitable, stable, and diversified which permit these corporations to keep smaller amount of cash. This specifies a negative relationship between cash holdings and size. In contrast, the pecking order theory suggests that big companies accomplish better and have more resources as cash than small companies do. Though, the previous studies have shown mixed impact of corporate size on cash holdings. Awadh Bukair and Rahman (2015), and Ahn and Chung (2015), show a negative impact, while Kariuki et al. (2015), and Shabbir et al. (2016), show a positive impact.

This paper includes a dummy variable (List) in the model to represent the impact of listing in the stock market on the level of cash holdings, as previously mentioned in the literature (e.g., Tasawar and Haniffa 2017). An additional variable is included in the robustness analysis, which is (Islam) to see to what extent bank type (Islamic or non-Islamic) may affect cash holding behavior. In addition, two macroeconomic variables; inflation and corruption are used as control variables in this paper, as they have been in previous studies (e.g., Chang and Noorbakhsh 2009; Anand et al. 2018). Several studies investigated inflation as a significant predictor of bank profitability, financial development, and capital structure (Wei and Kong 2017; Bougatef 2017). According to Ramírez and Tadesse (2009), inflation is likely to have a negative impact on corporate cash holdings. Previous studies have identified corruption as one of the factors that can have an impact on the banking system. (e.g., Zarrouk et al. 2016; Yong and Floros 2012). Pinkowitz et al. (2003) found that cash holding levels are positively related to country corruption. Similar conclusions were reached by Chang and Noorbakhsh (2009). In addition, a third variable, foreign exchange rate system, was added to control the impact of macroeconomic factors on cash holding. This paper expects a negative relationship between exchange rate and cash holdings. This expectation matches the result of Anand et al. (2018). To investigate the relationship between cash holdings and culture, in addition to control variables, this paper constructs regression equations based on model (0) and specifically based on model (1) as follows:

$$
\mathrm{CASH}_{\mathrm{it}}=\alpha+\beta 1 \mathrm{CULTURE}_{\mathrm{it}}+\beta 2 \mathrm{CONTROL}_{\mathrm{it}}+\varepsilon(0)
$$


Model 1: Impact of culture on cash holdings with control variables

$$
\begin{aligned}
\text { CASH1 }_{\text {it }}= & \alpha+\beta_{1} \mathrm{POW}_{i t}+\beta_{2} \mathrm{IND}_{\text {it }}+\beta_{3} \mathrm{MAS}_{\mathrm{it}}+\beta_{4} \mathrm{UNC}_{\mathrm{it}}+\beta_{5} \mathrm{LTO}_{\mathrm{it}}+ \\
& \beta_{6} \mathrm{SIZE}_{\mathrm{it}}+\beta_{7} \mathrm{ROA}_{\mathrm{it}}+\beta_{8} \mathrm{LEV}_{\mathrm{it}}+\beta_{9} \mathrm{LIST}_{\mathrm{it}}+\varepsilon
\end{aligned}
$$

where: CASH1 refers to cash holdings through dividing total cash and cash equivalents by total assets; $\mathrm{CASH} 2$ is defined as the natural logarithm of cash ratio (i.e., ratio of cash and cash equivalents over total assets); $i$ and $t$ denote bank and year. Culture, based on Hofstede model, includes 5 Dimensions: POW power distance, IND individualism, MAS masculinity, UNC Uncertainty avoidance, and LTO Long Term Orientation; SIZE is based on the total assets, ROA is return on assets which refers to the financial performance; LEV refers to leverage through dividing total liabilities over Total assets; LIST where 1 if the bank is listed in the stock market, 0 if bank is not listed, and $\varepsilon$ is the error term.

\begin{tabular}{|c|c|c|}
\hline Variables & Definitions & Source \\
\hline \multicolumn{3}{|c|}{ Dependent variable } \\
\hline Cash holdings ratio & $\begin{array}{l}\text { Total cash and cash equivalents over total assets } \\
\text { Logarithm of total cash and cash equivalents over total assets }\end{array}$ & Bank scope and annual reports \\
\hline \multicolumn{3}{|c|}{ Independent variables } \\
\hline Power distance (PD) & $\begin{array}{l}\text { The degree to which the less powerful members of a society accept and } \\
\text { expect that power is distributed unequally. }\end{array}$ & \multirow{5}{*}{$\begin{array}{c}\text { Hofstede (1980, 2001, 2010) } \\
\text { https:/ /hi.hofstede-insights.com/nationa } \\
\text { l-culture } \\
\text { (accessed on } 20 \text { July 2021) }\end{array}$} \\
\hline Individualism & $\begin{array}{l}\text { The preference for a loosely knit social framework in which individuals } \\
\text { are expected to take care of only themselves and their } \\
\text { immediate families }\end{array}$ & \\
\hline Masculinity & $\begin{array}{l}\text { It represents a preference in society for achievement, heroism, } \\
\text { assertiveness, and material rewards for success. Society at large is } \\
\text { more competitive }\end{array}$ & \\
\hline $\begin{array}{l}\text { Uncertainty avoidance } \\
\text { (UA) }\end{array}$ & $\begin{array}{l}\text { The degree to which the members of a society feel uncomfortable with } \\
\text { uncertainty and ambiguity. }\end{array}$ & \\
\hline $\begin{array}{l}\text { Long Term Orientation } \\
\text { (LTO) }\end{array}$ & $\begin{array}{l}\text { Societies with a high score, take a more pragmatic approach by } \\
\text { encourage thrift and efforts in modern education to prepare for } \\
\text { the future. }\end{array}$ & \\
\hline \multicolumn{3}{|c|}{ Control variables: Corporate characteristics } \\
\hline Size & Natural logarithm of total assets & \multirow{4}{*}{ Bank scope and annual reports } \\
\hline Listed & $\begin{array}{c}\text { Dummy variable: } 1 \text { if the bank is listed in the stock market and } \\
0 \text { otherwise }\end{array}$ & \\
\hline Leverage & Measured by Total liabilities (non-current + current) over total assets & \\
\hline Financial performance & $\begin{array}{l}\text { ROA: Retune on assets } \\
\text { ROE: Return on equity }\end{array}$ & \\
\hline Bank Type & Dummy variable: 1 if the bank is Islamic and 0 otherwise & Annual reports \\
\hline \multicolumn{3}{|c|}{ Control variables: Country characteristics } \\
\hline Inflation & $\begin{array}{l}\text { Inflation rate is calculated by annual growth rate of Gross domestic } \\
\text { product implicit deflator displays the rate of price variation in economy } \\
\text { as a whole }\end{array}$ & $\begin{array}{c}\text { World bank database } \\
\text { https:/ / data.worldbank.org/indicator/N } \\
\text { Y.GDP.DEFL.KD.ZG.AD (accessed on } \\
\text { 18 July 2021) }\end{array}$ \\
\hline Control of Corruption & $\begin{array}{l}\text { Corruption level is imitating views of the extent to which public power } \\
\text { is trained for private gain, comprising petty and grand forms of } \\
\text { corruption and capture of the state through bests and private interests }\end{array}$ & $\begin{array}{l}\text { Worldwide Governance Indicators (WGI) } \\
\text { http: } \\
\text { //info.worldbank.org/governance/wgi/ } \\
\text { https://datacatalog.worldbank.org/data } \\
\text { set/worldwide-governance-indicators } \\
\text { (accessed on 21 July 2021) }\end{array}$ \\
\hline $\begin{array}{l}\text { Foreign Exchange Rate } \\
\text { System }\end{array}$ & $\begin{array}{l}\text { Is how a nation managing its currency in the foreign exchange market. } \\
\text { Measured as a dummy variable by giving } 1 \text { if the Foreign Exchange } \\
\text { Rate System in the country is floating system and } 0 \text { otherwise as a } \\
\text { fixed system }\end{array}$ & $\begin{array}{l}\text { World bank database } \\
\text { https: / / data.worldbank.org/indicator/P } \\
\text { A.NUS.FCRF (accessed on } 23 \text { July 2021) }\end{array}$ \\
\hline
\end{tabular}

Table 1. Variables, definitions, and sources. 


\section{Empirical Analysis and Discussion}

\subsection{Descriptive and Correlation Analysis}

Table 2 indicates the statistics summary for Hofstede's cultural variables and financial variables as well as macroeconomic variables across the whole sample. The table shows that overall median for corporate cash holdings is 0.1039 across 19 countries. This result is consistent with previous studies such as one conducted by Chen et al. (2015), which measures corporate cash holdings in a different context and finds that the overall average of cash holdings level is 0.107 through 41 countries such as Canada, the United States of America, and European countries. The highest variable is PD by 7.62, and the lowest variable is LTO by 2.5. The result related to Hofstede dimensions of culture variables illustrates a slight score for five variables (less than 10). Table 2 reveals that $33 \%$ of the selected banks are listed on the stock exchange, with $25 \%$ of the sample being Islamic banks and the remaining being conventional banks. The average total assets are 5.50 while average leverage degree is 1.20 . The average rate of ROA is positive for the sample by 0.035 . The average level of inflation is 6.620 and average corruption for the selected countries is negative by -0.175 .

Table 2. Descriptive analysis.

\begin{tabular}{cccccccc}
\hline & $\mathbf{N}$ & Minimum & Maximum & Mean & Std. Deviation & Skewness & Kurtosis \\
\hline CASH & 6354 & 1.4761 & 2.5631 & 0.1039 & 0.192849 & -0.096 & 21.353 \\
PD & 6354 & 13.000 & 95.00 & 7.6429 & 13.92750 & -2.024 & 6.407 \\
INDIV & 6354 & 20.000 & 59.00 & 3.6801 & 9.07610 & 0.530 & -0.109 \\
MASC & 6354 & 40.000 & 65.00 & 5.1447 & 6.24436 & 0.062 & -0.089 \\
UA & 6354 & 54.000 & 96.00 & 7.1746 & 8.75166 & 0.791 & 0.848 \\
LTO & 6354 & 0.000 & 70.00 & 2.5005 & 15.41297 & 1.109 & 1.910 \\
LIST & 6354 & 0 & 1 & 0.33 & 0.471 & 0.710 & -1.497 \\
SIZE & 5392 & 2.00 & 8.00 & 5.5027 & 0.63282 & -0.412 & 0.451 \\
LEVE & 5217 & 0.0021 & 101.166 & 1.2090 & 2.80698 & 22.997 & 745.937 \\
ROA & 5205 & -7.314 & 9.1502 & 0.0356 & 0.34821 & 12.152 & 473.423 \\
ISLAM & 6347 & 0.00 & 1.00 & 0.2469 & 0.4312 & 1.174 & -0.621 \\
INFL & 6354 & -2.53127 & 7.11480 & 6.62017 & 1.0495895 & 1.519 & 8.105 \\
CORRU & 6354 & -1.61 & 1.72 & -0.1752 & 0.72873 & 0.058 & -0.806 \\
FER & 6300 & 0 & 1 & 0.51 & 0.500 & 1.658 & -0.981 \\
\hline
\end{tabular}

The following figures show the development of cash holdings regarding the average per year from 1999 to 2014 and the average per country during this period. According to Figure 1 and with emphasis on the number of selected banks in each country, Libya (0.50), Iraq (0.048), then Syria (0.023) are the highest countries holding cash in the sample. This result can be justified through the unstable political situation in these countries, which inspired the banks to hold more cash for avoiding investment risk in those exceptional circumstances in addition to lack of investment opportunities. This result demonstrates the extent to which crises, such as war, have driven corporations to hold more cash. Regarding the evolution of cash holding levels during the study period, Figure 2 shows that the level of cash holding has increased from 0.081 in 1999 to 0.173 in 2010. This increase in cash holding is in line with global statistics, which show that countries and businesses around the world are increasingly holding more cash. 


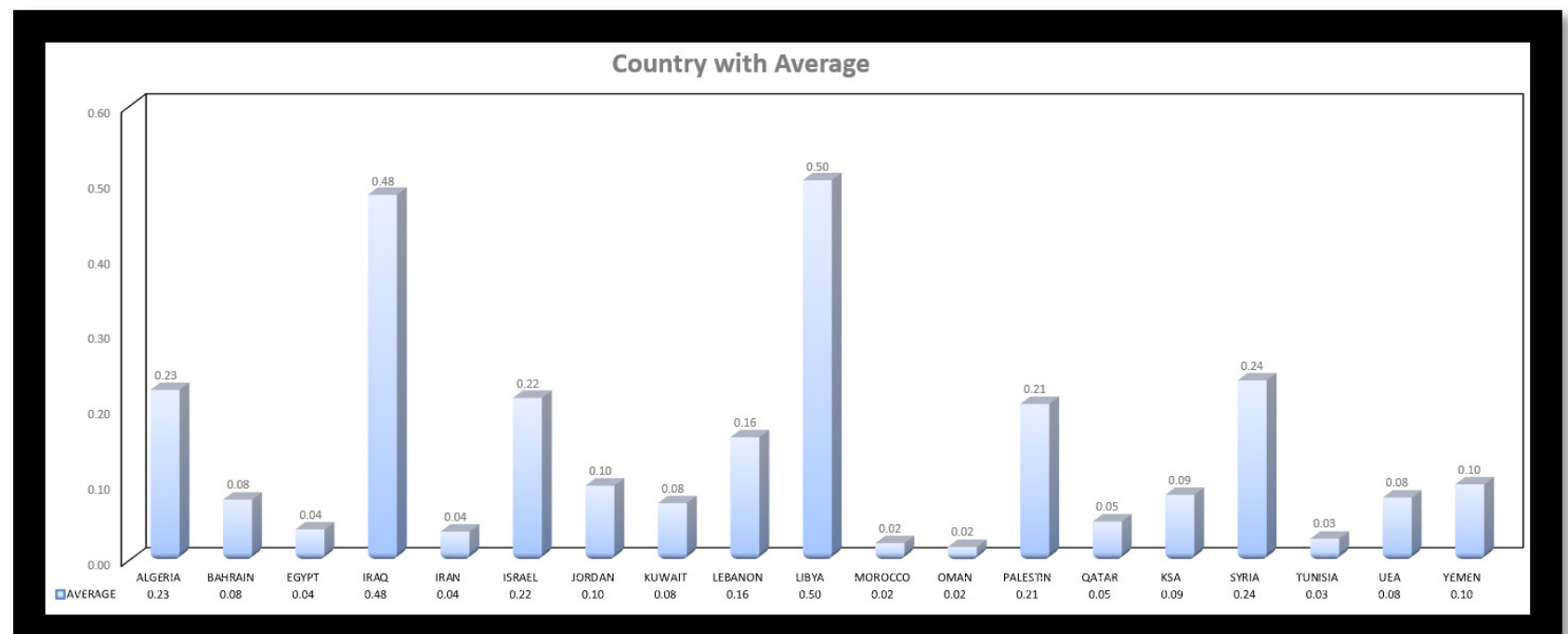

Figure 1. Average cash holding level per country.

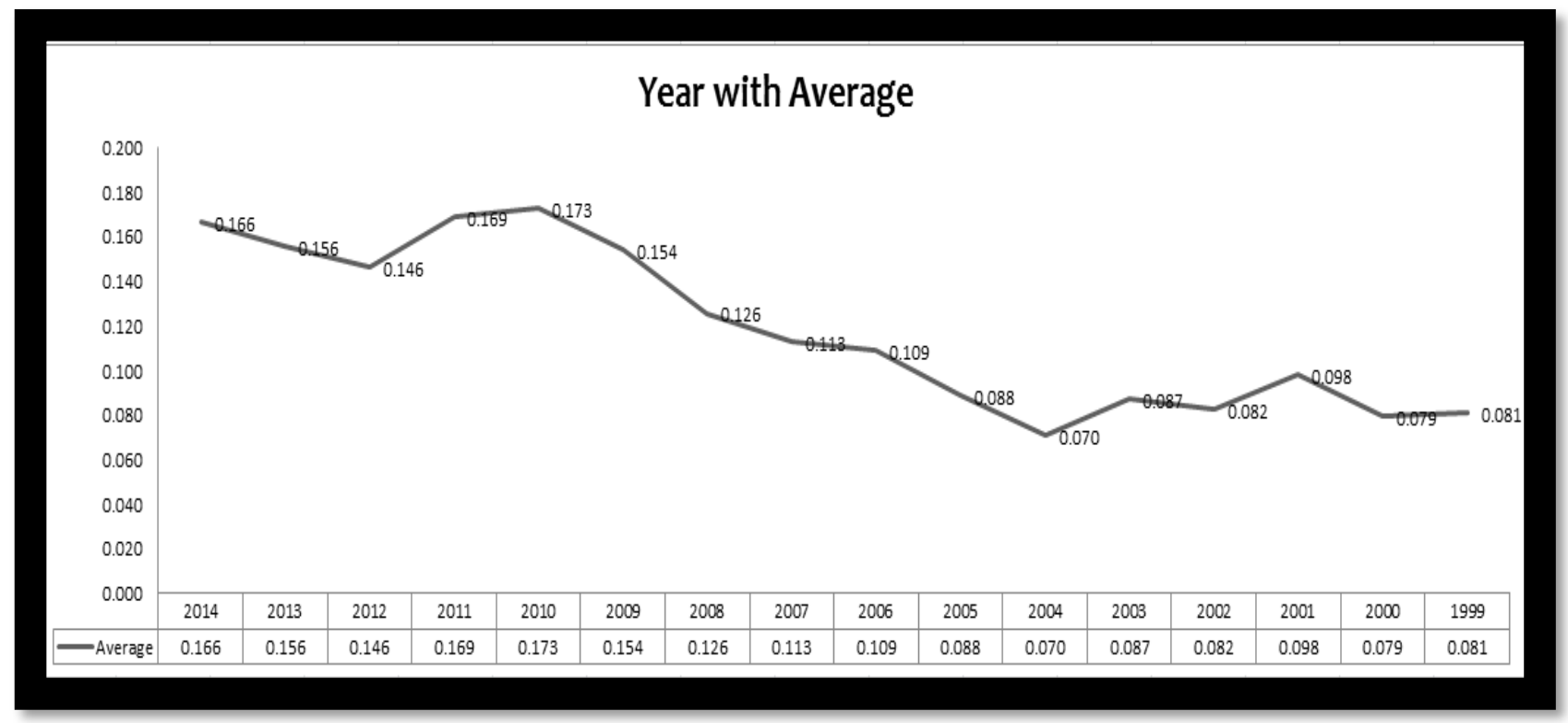

Figure 2. Average cash holding level per year.

Table 3 shows the correlation coefficients between the dependent variable, cash holdings, and the independent variable, culture, as well as other relevant control factors related to firm and country characteristics. The associations between cultural variables and cash holding supported the predictable significant negative signs. The analysis reveals a negative association between cash holdings and four cultural dimensions: PD, UA, Masculinity, and LTO. Regarding control variables, the correlation coefficient confirms a negative relationship with size, whereas it finds a positive association with leverage and ROA. 
Table 3. Correlation analysis.

\begin{tabular}{|c|c|c|c|c|c|c|c|c|c|c|}
\hline & CASH & PD & INDIV & MASC & UA & LTO & LIST & SIZE & LEVE & ROA \\
\hline CASH & 1.00 & $-0.052^{* *}$ & 0.024 & $-0.044^{*}$ & $-0.258^{* *}$ & $-0.066^{* *}$ & 0.007 & $-0.056^{* *}$ & $0.067 * *$ & $0.045^{*}$ \\
\hline PD & & 1.00 & $-0.707^{* *}$ & $0.349 * *$ & 0.002 & $-0.040^{* *}$ & 0.004 & $-0.051 * *$ & -0.035 & 0.001 \\
\hline INDIV & & & 1.00 & $0.075^{* *}$ & $0.094^{* *}$ & $0.199 * *$ & $-0.141^{* *}$ & $-0.098^{* *}$ & $0.064^{* *}$ & 0.005 \\
\hline MASC & & & & 1.00 & $-0.151^{* *}$ & $0.333^{* *}$ & $-0.291^{* *}$ & $-0.169^{* *}$ & 0.039 & -0.001 \\
\hline UA & & & & & 1.00 & $0.276^{* *}$ & -0.013 & $0.178^{* *}$ & $-0.085^{* *}$ & -0.007 \\
\hline LTO & & & & & & 1.00 & $-0.035^{* *}$ & 0.005 & 0.008 & -0.010 \\
\hline LIST & & & & & & & 1.00 & $0.178 * *$ & $-0.050 *$ & -0.002 \\
\hline SIZE & & & & & & & & 1.00 & $-0.167^{* *}$ & -0.042 * \\
\hline LEVE & & & & & & & & & 1.00 & 0.038 \\
\hline ROA & & & & & & & & & & 1.00 \\
\hline
\end{tabular}

* and ${ }^{* *}$ denotes significance at the $10 \%$ and $5 \%$ level, respectively.

\subsection{Regression Analysis and Discussion}

The regression result is presented in Table 4 for the main objective of this paper which is the impact of culture on the cash holdings. The analysis demonstrates that the level of cash holdings is negatively associated with UA and masculinity, while it shows positive relationship with individualism, PD, and LTO. The coefficient of PD, individualism, and LTO is positive and statistically significant at the levels of $10 \%, 1 \%$, and $5 \%$, respectively, whereas the coefficient of UA and Masculinity is negative and statistically significant at the $1 \%$ level for both of them. Based on these results, the last three hypotheses $(\mathrm{H} 3-\mathrm{H} 4$ and $\mathrm{H} 5)$ are accepted while $\mathrm{H} 1$ and $\mathrm{H} 2$ are rejected. Concerned with the positive coefficient of PD, hypothesis 4 is accepted, confirming that higher levels of cultural risk aversion are directly linked to higher levels of cash holdings. This result supports the assumption that banks in societies with a high level of PD seek to hold a large amount of cash. This result is justifiable because decision makers in a high PD society typically do not need to justify their financial decisions, such as holding cash This finding supports the free cash flow theory, which suggests that boards of directors usually hold large cash reserves in order to increase their discretionary powers over the company's investment decisions.

In addition, the observed direct relationship between LTO and cash holdings, as suggested by the positive sign of the latter variable's coefficient, confirms hypothesis 5 . This finding indicates that banks in countries or markets characterized and preoccupied with a long-term orientation are eager to hold a higher level of cash. This result is in line with Ali (2021) and Chang and Noorbakhsh (2009). This result also reflects the extent to which bank managers who are motivated by long-term goals adopt a cash-holding strategy in order to invest and archive sustainable development. This result corresponds to the precaution motive for holding cash, which trade-off theory recommends when businesses keep excess cash to ensure their continued ability to invest in profitable projects in the long run even when they are very short on cash compared with investments required. The positive coefficient of individualism validates the third hypothesis and shows that banks in countries with high level of individualistic culture, hold more cash. This finding is consistent with the findings of Orlova et al. (2017), who find that a high level of individualism is associated with extraordinary cash holding. In the MENA region, individualism is accelerating, upsetting societies which had relied on people and managers to know their place and respect authority. Managers in countries with a high level of individualism are more concerned with their own interests than with the wealth of stockholders and the needs of stakeholders. They are more likely to keep cash for their own benefit. The negative sign of the masculinity coefficient reflects the fact that financial managers in countries with high masculine cultures tend not to keep cash. This result can be justified by the managers' attitudes in this context toward investing more, increasing profitability, and then acquiring more compensations. Furthermore, in high masculinity societies, managers place a greater emphasis on increasing investment levels because superior financial performance from these investments would provide them with more self-esteem and social appreciation. As the MENA region has a high level of masculinity, bank managers tend to keep a low level of cash by increasing their level of investing. The negative coefficient of 
UA leads to the rejection of the first hypothesis, revealing that higher UA is associated with a lower level of cash holdings. While Orlova et al. (2017) support this negative association, other researchers have found a positive relationship (e.g., Chang and Noorbakhsh 2009; Ramírez and Tadesse 2009). A justification for this negative association is that managers in environments with a higher level of UA are more risk-averse and more concerned about costs, leading them to hold less cash. In actual fact, managers tend to hold less cash in markets with high UA, such as the markets in MENA region. This result can be also explained by the pecking theory, which states that investing through internal sources is less expensive than investing through external sources. Finally, the results of control variables are consistent with previous studies (e.g., Dittmar and Duchin 2011; Bates et al. 2009). These results confirm that the level of cash holdings is positively related to financial performance using ROA and leverage, but negatively related to corporate size.

Table 4. Model 1: Impact of national culture on the cash holdings.

\begin{tabular}{|c|c|c|c|c|c|}
\hline \multirow{2}{*}{ Model } & \multicolumn{2}{|c|}{$\begin{array}{c}\text { Unstandardized } \\
\text { Coefficients }\end{array}$} & \multirow{2}{*}{$\begin{array}{c}\begin{array}{c}\text { Standardized } \\
\text { Coefficients }\end{array} \\
\text { Beta }\end{array}$} & \multirow{2}{*}{$\mathbf{T}$} & \multirow{2}{*}{ Sig. } \\
\hline & B & Std. Error & & & \\
\hline (Constant) & 0.411 & 0.035 & & 11.835 & 0.000 \\
\hline PD & 0.001 & 0.000 & 0.053 & 2.380 & 0.017 * \\
\hline INDIV & 0.001 & 0.000 & 0.071 & 3.413 & $0.001^{* * *}$ \\
\hline MASC & -0.002 & 0.000 & -0.104 & -5.889 & $0.000^{* * *}$ \\
\hline UA & -0.003 & 0.000 & -0.207 & -14.793 & $0.000^{* * *}$ \\
\hline LTO & 0.000 & 0.000 & 0.033 & 2.277 & 0.023 * \\
\hline LIST & -0.004 & 0.004 & -0.012 & -0.944 & 0.345 \\
\hline SIZE & -0.008 & 0.004 & -0.026 & -2.057 & 0.040 \\
\hline LEVE & 0.002 & 0.001 & 0.024 & 1.961 & 0.050 \\
\hline ROA & 0.016 & 0.008 & 0.024 & 1.974 & 0.048 \\
\hline Model Summary & \multicolumn{2}{|c|}{ Adjusted R square 0.40} & F 31.316 & & Sig 0.000 \\
\hline
\end{tabular}

\subsection{Robustness Tests}

This paper employs a number of tests to validate the robustness of the previous analysis. ROA has been replaced with return on equity (ROE) in the first robustness test to examine the impact of firm value on the relationship between cash holding level and culture. The coefficients of the five culture variables continue to maintain both their statistical significance and their signs. As the sample includes 100 Islamic institutions and 295 non-Islamic institutions, the second robustness test measures the impact of bank type, Islamic or non-Islamic, on the relationship between culture and cash holdings. The signs and statistical significance for coefficients of the five culture variables remain the same after controlling bank type as provided in Table 5 . This result reflects the insignificant difference in the influence of culture on the level of cash holdings between Islamic and non-Islamic banks. This could be due to the fact that whether or not a bank follows Islamic Sharia has no bearing on the decision to keep a certain amount of cash.

Model 2: Impact of culture on cash holdings with control nature of bank (Islamic-Conventional)

$$
\begin{gathered}
\text { CASH1 }_{\text {it }}=\alpha+\beta_{1} \mathrm{POW}_{\text {it }}+\beta_{2} \mathrm{IND}_{\text {it }}+\beta_{3} \mathrm{MAS}_{\text {it }}+\beta_{4} \mathrm{UNC}_{\text {it }}+\beta_{5} \mathrm{LTO}_{\text {it }}+ \\
\beta_{6} \mathrm{SIZE}_{\mathrm{it}}+\beta_{7} \mathrm{ROA}_{\text {it }}+\beta_{8} \mathrm{LEV}_{\text {it }}+\beta_{9} \mathrm{LIST}_{\text {it }}+\beta_{10} \mathrm{ISLAM}_{\mathrm{it}}+\varepsilon
\end{gathered}
$$


Table 5. Model 2: Results with control bank type (Islamic or Non-Islamic).

\begin{tabular}{|c|c|c|c|c|c|}
\hline \multirow{2}{*}{ Variables } & \multicolumn{2}{|c|}{$\begin{array}{c}\text { Unstandardized } \\
\text { Coefficients }\end{array}$} & \multirow{2}{*}{$\begin{array}{c}\begin{array}{c}\text { Standardized } \\
\text { Coefficients }\end{array} \\
\text { Beta }\end{array}$} & \multirow{2}{*}{$\mathbf{T}$} & \multirow{2}{*}{ Sig. } \\
\hline & B & Std. Error & & & \\
\hline (Constant) & 0.409 & 0.035 & & 11.774 & 0.000 \\
\hline PD & 0.001 & 0.000 & 0.054 & 2.446 & 0.014 * \\
\hline INDIV & 0.001 & 0.000 & 0.074 & 3.593 & $0.000^{* * *}$ \\
\hline MASC & -0.002 & 0.000 & -0.105 & -5.968 & $0.000^{* * *}$ \\
\hline UA & -0.003 & 0.000 & -0.207 & -14.809 & $0.000^{* * *}$ \\
\hline LTO & 0.000 & 0.000 & 0.032 & 2.251 & $0.024 *$ \\
\hline ISLAM & 0.011 & 0.004 & 0.035 & 2.819 & 0.005 \\
\hline LIST & -0.004 & 0.004 & -0.013 & -1.004 & 0.316 \\
\hline SIZE & -0.008 & 0.004 & -0.027 & -2.148 & 0.032 \\
\hline LEVE & 0.002 & 0.001 & 0.024 & 1.966 & 0.049 \\
\hline ROA & 0.016 & 0.008 & 0.023 & 1.880 & 0.060 \\
\hline Model Summary & \multicolumn{2}{|c|}{ Adjusted R square 0.41} & \multicolumn{2}{|l|}{ F 28.109} & Sig 0.000 \\
\hline
\end{tabular}

In the third robustness test, an alternative method to measure cash holdings has been used in model 4. In this method, cash holding is calculated through the natural logarithm of cash percentage (ratio of cash and cash equivalents over total assets). This definition has been used in some previous studies such as Bates et al. (2009) and Opler et al. (1999). Table 6 shows the result of regression analysis for this additional test. It essentially not identical to those attained through adopting the original ratio of cash. The findings show that cash holdings are negatively related to LTO while being positively related to individualism and power distance, whereas the results show that masculinity and uncertainty avoidance have no effect on corporate cash holdings. The analysis shows that coefficient of PD; individualism and LTO are statistically significant at $1 \%$.

Model 3: Impact of culture on cash holdings with adopting alternative definitions of cash

$$
\begin{aligned}
\mathrm{CASH} 2_{\text {it }}= & \alpha+\beta_{1} \mathrm{POW}_{\text {it }}+\beta_{2} \mathrm{IND}_{\text {it }}+\beta_{3} \mathrm{MAS}_{\mathrm{it}}+\beta_{4} \mathrm{UNC}_{\mathrm{it}}+\beta_{5} \mathrm{LTO}_{\mathrm{it}}+ \\
& \beta_{6} \mathrm{SIZE}_{\mathrm{it}}+\beta_{7} \mathrm{ROA}_{\mathrm{it}}+\beta_{8} \mathrm{LEV}_{\mathrm{it}}+\beta_{9} \mathrm{LIST}_{\mathrm{it}}+\varepsilon
\end{aligned}
$$

where: The dependent variable is CASH ratio, defined as the natural logarithm of cash ratio (i.e., ratio of cash and cash equivalents over total assets).

Table 6. Model 3: Results with alternative definitions of cash holdings.

\begin{tabular}{cccccc}
\hline \multirow{2}{*}{ Model } & \multicolumn{2}{c}{$\begin{array}{c}\text { Unstandardized } \\
\text { Coefficients }\end{array}$} & $\begin{array}{c}\text { Standardized } \\
\text { Coefficients }\end{array}$ & \multirow{2}{*}{ T } & Sig. \\
\cline { 2 - 4 } & $\mathbf{B}$ & Std. Error & Beta & & \\
\hline (Constant) & -1.629 & 0.134 & & -12.114 & 0.000 \\
PD & 0.002 & 0.001 & 0.061 & 2.701 & $0.007^{*}$ \\
INDIV & 0.003 & 0.001 & 0.049 & 2.323 & $0.020^{*}$ \\
MASC & -0.001 & 0.002 & -0.012 & -0.672 & 0.501 \\
UA & 0.000 & 0.001 & -0.013 & -0.940 & 0.347 \\
LTO & -0.002 & 0.000 & -0.044 & -3.038 & $0.0022^{*}$ \\
LIST & 0.029 & 0.015 & 0.026 & 1.960 & 0.050 \\
SIZE & 0.027 & 0.015 & 0.024 & 1.842 & 0.066 \\
LEVE & -0.001 & 0.004 & -0.004 & -0.342 & 0.733 \\
ROA & -0.031 & 0.032 & -0.012 & -0.964 & 0.335 \\
Model Summary & Adjusted R square 0.50 & & F 3.334 & & Sig 0.000 \\
\hline * denotes significance at the $10 \%$ level.
\end{tabular}


In the fourth robustness test, this paper added to the model two macroeconomic variables, which are inflation and corruption and the analysis presented in Table 7 . Control of Corruption is one of the dimensions for the Worldwide Governance Indicators (WGI) project. The WGI reports on six broad dimensions of governance for over 200 countries and territories, initiated by Daniel Kaufmann and Aart Kraay and summarizing the views on the quality of governance for countries. Control of Corruption is adopted by previous studies (e.g., Elamer et al. 2020). The results for model 5 are similar to those reached through the main model in Table 4. The results display that cash holdings are negatively associated with UA and masculinity, whereas they are positively associated with PD and LTO while the result shows insignificant association with individualism. Coefficient of PD and LTO is positive and statistically significant at $10 \%$ and $1 \%$ level, respectively, whereas the coefficient of masculinity and UA is negative and statistically significant at the $1 \%$ level for both of them. Further, the coefficient of inflation is positive significant at the $1 \%$ level with cash holdings, whereas the coefficient of corruption has a negative relationship with cash holdings at the $1 \%$ level. Even after controlling for country variables, these results show that corporate cash holdings are influenced by culture.

Model 4: Impact of culture on cash holdings with control the inflation and corruption

$$
\begin{aligned}
& \text { CASH1 it }=\alpha+\beta_{1} \text { POW }_{\text {it }}+\beta_{2} \text { IND }_{i t}+\beta_{3} \text { MAS }_{i t}+\beta_{4} \text { UNC }_{i t}+\beta_{5} \text { LTO }_{i t}+ \\
& \beta_{6} \text { SIZE }_{i t}+\beta_{7} \text { ROA }_{i t}+\beta_{8} \text { LEV }_{\text {it }}+\beta_{9} \text { LIST }_{\text {it }}+\beta_{10} \text { INFLA }_{i t}+\beta_{11} \text { CORRU }+\varepsilon
\end{aligned}
$$

\begin{tabular}{|c|c|c|c|c|c|c|c|}
\hline \multirow{2}{*}{ Model } & \multicolumn{2}{|c|}{ Unstandardized Coefficients } & \multirow{2}{*}{$\begin{array}{c}\text { Standardized } \\
\text { Coefficients }\end{array}$} & \multirow[t]{2}{*}{$\mathbf{T}$} & \multirow{2}{*}{ Sig. } & \multirow{2}{*}{ Tolerance } & \multirow{2}{*}{ VIF } \\
\hline & B & Std. Error & & & & & \\
\hline (Constant) & 0.420 & 0.039 & & 10.909 & 0.000 & & \\
\hline PD & 0.000 & 0.000 & 0.067 & 3.019 & $0.003^{* *}$ & 0.310 & 3.229 \\
\hline INDIV & 0.000 & 0.000 & 0.030 & 1.322 & 0.186 & 0.288 & 3.476 \\
\hline MASC & -0.002 & 0.000 & -0.098 & -5.305 & $0.000 * * *$ & 0.446 & 2.241 \\
\hline UA & -0.002 & 0.000 & -0.115 & -5.782 & $0.000 * * *$ & 0.384 & 2.603 \\
\hline LTO & 0.000 & 0.000 & 0.063 & 4.405 & $0.000^{* * *}$ & 0.734 & 1.363 \\
\hline LIST & -0.006 & 0.003 & -0.027 & -2.108 & $0.035 *$ & 0.918 & 1.090 \\
\hline SIZE & 0.149 & 0.022 & 0.086 & 6.850 & $0.000^{* * *}$ & 0.959 & 1.043 \\
\hline LEVE & 0.001 & 0.001 & 0.017 & 1.353 & 0.176 & 0.961 & 1.040 \\
\hline ROA & -0.006 & 0.003 & -0.027 & -1.898 & $0.058 *$ & 0.758 & 1.319 \\
\hline Inflation & 0.000 & 0.000 & 0.068 & 5.411 & $0.000^{* * *}$ & 0.958 & 1.044 \\
\hline Corruption & -0.028 & 0.003 & -0.176 & -9.293 & $0.000^{* * *}$ & 0.426 & 2.345 \\
\hline Model Summary & \multicolumn{2}{|c|}{ Adjusted R square 0.302} & \multicolumn{2}{|c|}{ F 54.489} & \multicolumn{3}{|c|}{ Sig 0.000} \\
\hline
\end{tabular}

Table 7. Model 4: Impact of inflation and corruption on the affiliation between culture and cash holdings.

${ }^{*},{ }^{* *}$ and ${ }^{* * *}$ denotes significance at the $10 \%, 5 \%$ and $1 \%$ level, respectively.

In the fifth robustness test, this paper examines the impact of the foreign exchange rate system on corporate cash holdings and how open the economies are to trade in areas where the effects of exchange rate volatility can be mitigated by cash balance, as formulated in model 5. This paper measure country foreign rate as a dummy variable (I if exchange rate System is floating and 0 if System is fixed). The results according to Table 8 show that cash holdings are negatively associated with uncertainty avoidance, PD, and masculinity at the $1 \%$ level, while results show insignificant association with individualism and LTO. Further, the coefficient of foreign exchange rate is negative and statistically significant at the $1 \%$ level with cash holdings. Even after controlling for the foreign exchange rate, these results show that show that corporate cash holdings are influenced by culture.

Finally, the results of control variables are consistent with previous studies (e.g., Dittmar and Duchin 2011; Bates et al. 2009). These results are consistent with the findings of Anand et al. (2018), who investigated the impact of macroeconomic factors (Gross domestic product, change in exchange rate; change in stock market index, long-term bond yield, and credit spread) on cash holding, which support the result. Concerning 
the exchange rate, they found that firms hold less cash in anticipation of an increase in exchange rate. Thus, changes in the foreign exchange rate system have significant influence on firms' cash holdings and have an impact as a meditator of linkage between cash holding and culture.

Model 5: Impact of culture on cash holdings with control the impact of foreign currency rate

$$
\begin{gathered}
\text { CASH1 }_{\text {it }}=\alpha+\beta_{1} \text { POW }_{\text {it }}+\beta_{2} \mathrm{IND}_{\text {it }}+\beta_{3} \mathrm{MAS}_{\text {it }}+\beta_{4} \mathrm{UNC}_{\text {it }}+\beta_{5} \mathrm{LTO}_{\text {it }}+ \\
\beta_{6} \mathrm{SIZE}_{\mathrm{it}}+\beta_{7} \mathrm{ROA}_{\mathrm{it}}+\beta_{8} \mathrm{LEV}_{\text {it }}+\beta_{9} \mathrm{FER}_{\text {it }}+\varepsilon
\end{gathered}
$$

\begin{tabular}{|c|c|c|c|c|c|c|c|}
\hline \multirow{2}{*}{ Model } & \multicolumn{2}{|c|}{ Unstandardized Coefficients } & \multirow{2}{*}{$\begin{array}{c}\begin{array}{c}\text { Standardized } \\
\text { Coefficients }\end{array} \\
\text { Beta }\end{array}$} & \multirow{2}{*}{$\mathbf{T}$} & \multirow{2}{*}{ Sig. } & \multirow{2}{*}{ Tolerance } & \multirow{2}{*}{ VIF } \\
\hline & B & Std. Error & & & & & \\
\hline (Constant) & 1.036 & 0.082 & & 12.576 & 0.000 & & \\
\hline PD & -0.002 & 0.000 & -0.157 & -4.839 & $0.000 * * *$ & 0.432 & 2.315 \\
\hline INDIV & 0.001 & 0.001 & 0.030 & 0.809 & 0.418 & 0.334 & 2.990 \\
\hline MASC & -0.003 & 0.001 & -0.144 & -4.540 & $0.000 * * *$ & 0.449 & 2.229 \\
\hline UA & -0.008 & 0.001 & -0.321 & -11.873 & $0.000 * * *$ & 0.621 & 1.610 \\
\hline LTO & 0.000 & 0.000 & 0.018 & 0.700 & 0.484 & 0.679 & 1.472 \\
\hline SIZE & -0.014 & 0.006 & -0.052 & -2.235 & 0.026 * & 0.834 & 1.199 \\
\hline LEVE & -0.001 & 0.001 & -0.012 & -0.526 & 0.599 & 0.931 & 1.074 \\
\hline ROA & 0.143 & 0.028 & 0.111 & 5.039 & $0.000^{* * *}$ & 0.939 & 1.065 \\
\hline FER System & -0.031 & 0.007 & -0.107 & -4.445 & $0.000^{* * *}$ & 0.787 & 1.270 \\
\hline Model Summary & \multicolumn{3}{|c|}{ Adjusted R square 0.175} & \multicolumn{2}{|c|}{ F 44.005} & \multicolumn{2}{|c|}{ Sig 0.000} \\
\hline
\end{tabular}

Table 8. Model 5: Impact of foreign exchange rate system on the association between culture and cash holdings.

* and ${ }^{* * *}$ denotes significance at the $10 \%$, and $1 \%$ level, respectively.

\section{Conclusions, Implications, and Suggestions for Further Research}

\subsection{Conclusions}

Several studies have been conducted to illustrate the implications of corporate cash holdings; other studies have focused on assessing the determinants of cash holdings; and only a few studies have been conducted to examine the impact of national culture on cash holdings. To the best of our knowledge, empirical studies examining this impact using data from banks across the MENA region are relatively rare in the literature.

This paper used data from 395 financial institutions across 19 countries in MENA region between 1999 and 2014. The analysis shows, consistent with our expectations, that banks in societies with high levels of UA and masculinity hold less amounts of cash balances and banks in societies with high levels of PD, LTO, and individualism hold more cash. In other words, cash holding levels are negatively associated with UA and masculinity, and are positively associated with individualism, PD, and LTO.

Several robustness checks were performed to ensure the validity of the empirical findings, including an alternative method of calculating cash holdings, controlling the nature of banks by dividing the sample into Islamic banks, and using a comprehensive set of control variables related to macroeconomic factors.

The findings provide strong support for the significance of cultural effect in determining cash holdings. The results of these additional analyses show that after controlling for corporate and macroeconomic characteristics associated with inflation, corruption, and exchange rate systems, the results are slightly different.

\subsection{Implications}

\subsubsection{Theoretical Implications}

This research contributes to a growing body of literature that has focused in investigating the effects of national culture on several issues, including financial systems, capital structure, and dividend policy. The findings also provide additional empirical evidence to support the agency theory, trade-off theory, and pecking order theory in the context of 
corporate cash holdings and culture in emerging markets such as the MENA region, an emerging market. The different results for some hypotheses, as well as their inconsistency with the theoretical foundations, explain how the results of applying the theory can vary depending on context and applied sample.

\subsubsection{Practical Implications}

The findings provide implications for policymakers, academics, and corporations. The results suggest that culture has a great impact on cash holdings. Especially in emerging markets, such as MENA region, where formal mechanisms are relatively less effective, informal institutions can serve an alternative system for alleviating adverse effects of agency conflicts. As a result, banks and other institutions will be guided and inspired to study well the atmosphere and culture of markets prior to investing money or making a managerial decision, such as holding cash. The literature indicates that cross-country comparisons should be considered because financial institutions' cash holding decisions differ from those of non-financial institutions. Despite the fact that national culture does influence corporate financial decisions, this paper emphasizes that it does not do so in an identical manner once macroeconomic factors such as inflation are considered. Thus, macroeconomic factors of a country should be considered when analyzing cultural impacts on financial decisions. The results conclude that exploring the active role of culture in holding cash should inspire further research on culture. The negative association with UA and masculinity, while the positive association with individualism, PD, and LTO, should inspire corporate managers to understand the characteristics of national culture and integrate it into their analyses of corporate decisions.

\subsection{Limitations and Future Researches}

While this study has made important contributions, there are some limitations which require further examination. Perhaps the addition of Gray's model to the present study could prove to be a promising avenue of further study. Moreover, future research may re-examine the relationship between culture and cash holdings by moderating corporate governance variables. Additionally, future research may use primary data through questionnaire to measure the impact of cultural characteristics of board members on cash holding decisions. Future research may also measure the impact of culture on other variables such as earnings management, credit rating, and firm value. While this study ends in 2014, future research may extend until 2020 to examine the impact of the COVID-19 pandemic on the relationship between culture and cash holdings. While this study focuses solely on financial institutions (banks), future research may compare the results of financial and non-financial institutions to see how they differ. Future research could take into consideration the impact of Islamic culture on corporate risk-taking in Islamic banks. Further research could also explore the impact of the changes in the inflation rate on the cash holdings-national culture relationship following the scenarios proposed by Esmaeili and Nasrabadi (2020). Further research could also explore the moderating role of the two-level trade credit policy proposed by Mandal et al. (2020) on the cash holding-national culture relationship. Finally, the authors believe that the study has scope for further refinement. At the moment, the focus is on the impact of national culture on cash holding, but there is a call for research that explicitly considers the interactions between firms' financing and investment decisions (Bui et al. 2020). Therefore, it would be interesting to examine the impact of national culture on the interactions between firms' financing and investment decisions.

Author Contributions: Conceptualization, H.A., S.E.-H. and K.H.; methodology, S.E.-H. and H.A.; software, S.E.-H.; validation, H.A. and S.E.-H.; formal analysis, S.E.-H. and H.A.; investigation, H.A. and S.E.-H.; resources, H.A. and S.E.-H.; data curation, S.E.-H.; writing—original draft preparation, H.A.; writing—review and editing, H.A., S.E.-H. and K.H.; visualization, H.A. and S.E.-H.; supervision, K.H.; project administration, H.A. and S.E.-H.; funding acquisition, H.A. All authors have read and agreed to the published version of the manuscript. 
Funding: This research was funded by [The research sector, Arab Open University-Kuwait Branch] grant number (21105).

Institutional Review Board Statement: Not applicable.

Informed Consent Statement: Not applicable.

Data Availability Statement: For Hofstede's dimensions data, the authors use Hofstede website https: / hi.hofstede-insights.com/national-culture. For several variables, the authors use Bank scope and annual reports of banks in MENA region. For control variables, the authors use World bank database; https:/ / data.worldbank.org/indicator/NY.GDP.DEFL.KD.ZG.AD; http:/ / info.worldba nk.org/governance/wgi/; https:/ / datacatalog.worldbank.org/dataset/worldwide-governance-i ndicators; https:/ / data.worldbank.org/indicator/PA.NUS.FCRF.

Acknowledgments: This research was supported and funded by the research sector, Arab Open University-Kuwait Branch, under decision number: 21105.

Conflicts of Interest: The authors declare no conflict of interest.

\section{References}

Achim, Monica Violeta, Sorin Nicolae Borlea, Lucian Vasile Găban, and Alin Adrian Mihăilă. 2019. The Shadow Economy and Culture: Evidence in European Countries. Eastern European Economics 57: 352-74. [CrossRef]

Ahern, Kenneth, Daniele Daminelli, and Cesare Fracassic. 2015. Lost in translation? The effect of cultural values on mergers around the world. Journal of Financial Economics 117: 165-89. [CrossRef]

Ahn, Seoungpil, and Jaiho Chung. 2015. Cash holdings, corporate governance, and acquirer returns. Financial Innovation 13: 1-31. [CrossRef]

Al-Najjar, Basil. 2013. The financial determinants of corporate cash holdings: Evidence from some emerging markets. International Business Review 22: 77-88. [CrossRef]

Al-Najjar, Basil, and Yacine Belghitar. 2011. Corporate cash holdings and dividend payments: Evidence from simultaneous analysis. Managerial \& Decision Economics 32: 231-41. [CrossRef]

Al-Najjar, Basil, and Ephraim Clark. 2017. Corporate governance and cash holdings in MENA: Evidence from internal and external governance practices. Research in International Business and Finance 39: 1-12. [CrossRef]

Ali, Alipour. 2021. What matters for the future? Comparing Globe's future orientation with Hofstede's long-term orientation. Cross Cultural \& Strategic Management 28: 734-59. [CrossRef]

Anand, Lalita, Thenmozhi Nikhil Varaiya, and Saumitra Bhadhuri. 2018. Impact of Macroeconomic Factors on Cash Holdings? A Dynamic Panel Model. Journal of Emerging Market Finance 17: S27-S52. [CrossRef]

Arosa, Clara Maria Verduch, Nivine Richie, and Peter Schuhmann. 2014. The impact of culture on market timing in capital structure choices. Research in International Business and Finance 31: 178-92. [CrossRef]

Bukair, Abdullah Awadh, and Azhar Abdul Rahman. 2015. Bank performance and board of directors' attributes by Islamic banks. International Journal of Islamic and Middle Eastern Finance and Management 8: 291-309. [CrossRef]

Bates, Thomas, Kahle Kathleen, and René Stulz. 2009. Why Do U.S. Firms Hold So Much More Cash Than They Used To? The Journal of Finance 64: 1985-2021. [CrossRef]

Beugelsdijk, Sjoerd, and Bart Frijns. 2010. A cultural explanation of the foreign bias in international asset allocation. Journal of Banking E Finance 34: 2121-31. [CrossRef]

Bitar, Mohammad, Kabir Hassan, and Wadad Saad. 2020. Culture and the capital-performance nexus in dual banking systems. Economic Modelling 87: 34-58. [CrossRef]

Bougatef, Khemaies. 2017. Determinants of bank profitability in Tunisia: Does corruption matter? Journal of Money Laundering Control 20: 70-78. [CrossRef]

Bui, Tat Dat, Mohd Helmi Ali, Feng Ming Tsai, Mohammad Iranmanesh, Ming-Lang Tseng, and Ming K. Lim. 2020. Challenges and Trends in Sustainable Corporate Finance: A Bibliometric Systematic Review. Journal of Risk and Financial Management 13: 264. [CrossRef]

Breuer, Wolfgang, Bushra Ghufran, and Astrid Juliane Salzmann. 2018. National culture, managerial preferences, and takeover performance. International Business Review 27: 1270-89. [CrossRef]

Byrne, Julie, and Thomas O'Connor. 2017. Creditor rights, culture and dividend pay-out policy. Journal of Multinational Financial Management 39: 60-77. [CrossRef]

Chang, Kiyoung, and Abbas Noorbakhsh. 2006. Corporate cash holdings, foreign direct investment, and corporate governance. Global Finance Journal 16: 302-16. [CrossRef]

Chang, Kiyoung, and Abbas Noorbakhsh. 2009. Does national culture affect international corporate cash holdings? Journal of Multinational Financial Management 19: 323-42. [CrossRef]

Chen, Shihua, Yan Ye, Khalil Jebran, and Muhammad Ansar Majeed. 2020. Confucianism culture and corporate cash holdings. International Journal of Emerging Markets 15: 1127-59. [CrossRef] 
Chen, Yangyang, Paul Dou, Ghon Rheec, Cameron Truong, and Madhu Veeraragh. 2015. National culture and corporate cash holdings around the world. Journal of Banking \& Finance 50: 1-18. [CrossRef]

Chourou, Lamia, Samir Saadi, and Hui Zhub. 2018. How does national culture influence IPO underpricing? Pacific-Basin Finance Journal 51: 318-41. [CrossRef]

Chui, Andy, and Chuck Kwok. 2008. National Culture and Life Insurance Consumption. Journal of International Business Studies 39: 88-101. [CrossRef]

Chui, Andy C. W., Sheridan Titman, and K. C. John Wei. 2010. Individualism and momentum around the world. Journal of Finance 65: 361-92. [CrossRef]

Deshmukh, Sanjay, Goel Anand, and Howe Keith. 2021. Do CEO beliefs affect corporate cash holdings? Journal of Corporate Finance 67: 101886. [CrossRef]

Dittmar, Amy, Jan Mahrt-Smith, and Henri Servaes. 2003. International corporate governance and corporate cash holdings. Journal of Financial and Quantitative Analysis 38: 111-33. [CrossRef]

Diez-Esteban, José María, Jorge Bento Farinha, and Conrado Diego García-Gómez. 2019. Are religion and culture relevant for corporate risk-taking? International evidence. Business Research Quarterly 22: 36-55. [CrossRef]

Dittmar, Amy, and Jan Mahrt-Smith. 2007. Corporate governance and the value of cash holdings. Journal of Financial Economics 83: 599-634. [CrossRef]

Dittmar, Amy, and Ran Duchin. 2011. Dynamics of Cash. Working Paper. Ann Arbo: University of Michigan.

Elamer, Ahmed, Collins Ntim, Hussein Abdou, Andrew Owusu, Mohamed Elmagrhi, and Awad Ibrahim. 2020. Are Bank Risk Disclosures Informative? Evidence from Debt Markets. International Journal of Finance and Economics 26: 1270-98. [CrossRef]

Esmaeili, Maryam, and Mehri Nasrabadi. 2020. An inventory model for single-vendor multi-retailer supply chain under inflationary conditions and trade credit. Journal of Industrial and Production Engineering 38: 75-88. [CrossRef]

Fauver, Larry, and Michael McDonald. 2015. Culture, agency costs, and governance: International evidence on capital structure. Pacific-Basin Finance Journal 34: 1-23. [CrossRef]

Fernandes, Nuno, and Halit Gonenc. 2016. Multinationals and cash holdings. Journal of Corporate Finance 39: 139-54. [CrossRef]

Ferreira, Miguel, and Antonio Vilela. 2004. Why do firms hold cash? Evidence from EMU countries. European Financial Management 10: 295-319. [CrossRef]

Foley, Fritz, Jay Hartzell, Sheridan Titman, and Garry Twite. 2007. Why do firms hold so much cash? A tax-based explanation. Journal of Financial Economics 86: 579-607. [CrossRef]

Gorodnichenko, Yuriy, and Gerard Roland. 2017. Culture, Institutions, and the Wealth of Nations. Review of Economics E Statistics 99: 402-16. [CrossRef]

Guiso, Luigi, Paola Sapienza, and Luigi Zingales. 2006. Does culture affect economic outcomes? Journal of Economic Perspectives 20: 23-48. [CrossRef]

Haj-Salem, Issal, and Khaled Hussainey. 2021. Risk Disclosure and Corporate Cash Holdings. Journal of Risk and Financial Management 14: 328. [CrossRef]

Haq, Marmiza, Daniel Hu, Robert Faff, and Shams Pathan. 2018. New evidence on national culture and bank capital structure. Pacific-Basin Finance Journal 50: 41-64. [CrossRef]

Harford, Jarrad, Sattar Mansi, and William Maxwell. 2008. Corporate governance and firm cash holdings in the US. Journal of Financial Economics 87: 535-55. [CrossRef]

Hofstede, Geert. 1980. Culture's Consequences: International Differences in Work-Related Values. Beverly Hills: Sage.

Hofstede, Geert. 2001. Culture's Consequences: Comparing Values, Behaviors, Institutions, and Organizations Across Nations, 2nd ed. Newbury Park: Sage Publications.

Hofstede, Geert. 2010. The GLOBE debate: Back to relevance. Journal of International Business Studies 41: 1339-46. [CrossRef]

Hope, Ole-Kristian, Tony Kang, Wayne Thomas, and Yong Keun Yoo. 2008. Culture and auditor choice: A test of the secrecy hypothesis. Journal of Accounting and Public Policy 27: 357-73. [CrossRef]

Jensen, Michael. 1986. Agency cost of free cash flow, corporate finance and takeovers. American Economic Review 76: 323-29. [CrossRef]

Kanagaretnam, Kiridaran, Chee Yeow Lim, and Gerald J. Lobo. 2014. Influence of national culture on accounting conservatism and risk-taking in the banking industry. The Accounting Review 89: 1115-49. [CrossRef]

Kariuki, Samuel, Gregory Namusonge, and George Orwa. 2015. Determinants of corporate cash holdings: Evidence from private manufacturing firms in Kenya. International Journal of Advanced Research in Management and Social Sciences 4: 15-33.

Kashefi-Pour, Eilnaz, Shima Amini, Moshfique Uddin, and Darren Duxbury. 2020. Does Cultural Difference Affect Investment-Cash Flow Sensitivity? Evidence from OECD Countries. British Journal of Management 31: 636-58. [CrossRef]

Keynes, Maynard. 1936. The General Theory of Employment, Interest and Money. London: Harcourt Brace.

Kim, Jiyoung, Hyunjoon Kim, and David Woods. 2011. Determinants of corporate cash-holding levels: An empirical examination of the restaurant industry. International Journal of Hospitality Management 30: 568-74. [CrossRef]

Kwok, Chuck, and Solomon Tadesse. 2006. National culture and financial systems. Journal of International Business Studies 37: $227-47$. [CrossRef]

Le, Duc Hoang, Phi Long Tran, Thu Phuong Ta, and Duy Minh Vu. 2018. Determinants of corporate cash holding: Evidence from UK listed firms. Business and Economic Horizons 14: 561-69. [CrossRef] 
Li, Yaoqin, Xichan Chen, Wanli Li, and Xixiong Xu. 2021. How does Buddhism affect corporate cash holdings? International Journal of Emerging Markets. ahead-of-print. [CrossRef]

Li, Kai, Dale Griffin, Heng Yue, and Longkai Zhao. 2013. How does culture influence corporate risk-taking? Journal of Corporate Finance 23: 1-22. [CrossRef]

Liu, Xiaoding. 2016. Corruption culture and corporate misconduct. Journal of Financial Economics 122: 307-27. [CrossRef]

Mandal, Anindya, Brojeswar Pal, and Kripasindhu Chaudhuri. 2020. Unreliable EPQ model with variable demand under two-tier credit financing. Journal of Industrial and Production Engineering 37: 370-86. [CrossRef]

Mittal, Rakesh, and Steven Elias. 2016. Social power and leadership in cross-cultural context. Journal of Management Development 35: 58-74. [CrossRef]

Mondal, Amitava, and Santanu Kumar Ghosh. 2012. Intellectual capital and financial performance of Indian banks. Journal of Intellectual Capital 13: 515-30. [CrossRef]

Myers, Stewart. 1977. Determinants of corporate borrowing. Journal of Financial Economics 5: 147-75. [CrossRef]

Myers, Stewart. 1984. The capital structure puzzle. The Journal of Finance 39: 575-92. [CrossRef]

Myers, Stewart, and Nicholas Majluf. 1984. Corporate financing and investment decisions when firms have information that investors do not have. Journal of Financial Economics 13: 187-221. [CrossRef]

Nash, Robert, and Ajay Patel. 2019. Instrumental variables analysis and the role of national culture in corporate finance. Financial Management 48: 385-416. [CrossRef]

Newman, Karen, and Stanley Nollen. 1996. Culture and congruence: The fit between management practices and national culture. Journal of International Business Studies 27: 753-79. [CrossRef]

Obiols, Maria. 2018. The World's Richest Companies 2018: Global Finance Cash. Global Finance 32: 1-24.

Opler, Tim, Lee Pinkowitz, René M. Stulz, and Rohan Williamson. 1999. The determinants and implications of corporate cash holdings. Journal of Financial Economics 52: 3-46. [CrossRef]

Ozkan, Aydin, and Neslihan Ozkan. 2004. Corporate cash holdings: An empirical investigation of UK companies. Journal of Banking $\mathcal{E}$ Finance 28: 2103-34. [CrossRef]

Ozkan, Serdar, Chadi Yaacoub, Nasser El-Kanj, and VIadimir Dzenopoljac. 2021. The Effect of IFRS Adoption on Corporate Cash Holdings: Evidence from MENA Countries. Emerging Markets Finance and Trade 57: 3275-300. [CrossRef]

Orlova, Svetlana, and Grant Harper. 2021. National culture and leverage adjustments. Review of Behavioral Finance. ahead-of-print. [CrossRef]

Orlova, Svetlana, Ramesh Rao, and Tony Kang. 2017. National culture and the valuation of cash holdings. Journal of Business Finance and Accounting 44: 236-70. [CrossRef]

Patricia, Bachiller, and Javier Garcia-Lacalle. 2018. Corporate governance in Spanish savings banks and its relationship with financial and social performance. Management Decision 56: 828-48. [CrossRef]

Pinkowitz, Lee, René M. Stulz, and Rohan Williamson. 2003. Do Firms in Countries with Poor Protection of Investor Rights hold More Cash? NBER Working Papers 10188. National Bureau of Economic Research, Inc. Available online: https://ideas.repec.org/p/nb $\mathrm{r} /$ nberwo/10188.html (accessed on 29 August 2021).

Prenker, Tomas, and Jens Kück. 2009. The Determinant of Corporate Cash Holdings. Master's thesis, School of Economics and Management, Lund University, Lund, Sweden.

Ramírez, Andrés, and Solomon Tadesse. 2009. Corporate cash holdings, uncertainty avoidance, and the multinationality of firms. International Business Review 18: 387-403. [CrossRef]

Seifert, Bruce, and Halit Gonenc. 2016. Creditor Rights, Country Governance, and Corporate Cash Holdings. Journal of International Financial Management \& Accounting 27: 65-90. [CrossRef]

Seifert, Bruce, and Halit Gonenc. 2018. The effects of country and firm-level governance on cash management. Journal of International Financial Markets, Institutions and Money 52: 1-16. [CrossRef]

Shabbir, Mohsin, Shujahat Haider Hashmi, and Ghulam Mujtaba Chaudhary. 2016. Determinants of corporate cash holdings in Pakistan. International Journal of Organizational Leadership 5: 50-62. [CrossRef]

Tasawar, Nawaz, and Roszaini Haniffa. 2017. Determinants of financial performance of Islamic banks: An intellectual capital perspective. Journal of Islamic Accounting and Business Research 8: 130-42. [CrossRef]

Tabellini, Guido. 2010. Culture and Institutions: Economic Development in the Regions of Europe. Journal of the European Economic Association 8: 677-716. [CrossRef]

Tran, Quoc Trung. 2020. Uncertainty avoidance culture, cash holdings and financial crisis. Multinational Business Review 28: 549-66. [CrossRef]

Tran, Ly Thi Hai, Thoa Thi Kim Tu, and Thao Thi Phuong Hoang. 2021. Managerial optimism and corporate cash holdings. International Journal of Managerial Finance 17: 214-36. [CrossRef]

Ucar, Erdem. 2018. Creative culture, risk-taking, and corporate financial decisions. European Financial Management 25: 684-717. [CrossRef]

Uyar, Ali, and Cemil Kuzey. 2014. Determinants of corporate cash holdings: Evidence from the emerging market of Turkey. Applied Economics 46: 1035-48. [CrossRef]

Van Den Steen, Eric. 2004. Rational Overoptimism (and Other Biases). American Economic Review 94: 1141-51. [CrossRef] 
Vandello, Joseph, and Dov Cohen. 1999. Patterns of individualism and collectivism across the United States. Journal of Personality and Social Psychology 77: 279-92. [CrossRef]

Wei, Feng, and Yu Kong. 2017. Corruption, financial development and capital structure: Evidence from China. China Finance Review International 7: 295-322. [CrossRef]

Yong, Tan, and Christos Floros. 2012. Bank profitability and inflation: The case of China. Journal of Economic Studies 39: 675-96. [CrossRef]

Zarrouk, Hajer, Khoutem Ben Jedidia, and Mouna Moualhi. 2016. Is Islamic bank profitability driven by same forces as conventional banks? International Journal of Islamic and Middle Eastern Finance and Management 9: 46-66. [CrossRef]

Zhang, Min, Wen Zhang, and Sheng Zhang. 2016. National culture and firm investment efficiency: International evidence. Asia-Pacific Journal of Accounting \& Economics 23: 1-21. [CrossRef]

Zheng, Changjun, and Badar Nadeem Ashraf. 2014. National culture and dividend policy: International evidence from banking. Journal of Behavioural and Experimental Finance 3: 22-40. [CrossRef]

Zheng, Xiaolan, Sadok El Ghoul, Omrane Guedhami, and Chuck C. Y. Kwok. 2012. National culture and corporate debt maturity. Journal of Banking $\mathcal{E}$ Finance 36: 468-88. [CrossRef]

Zhou, Meihua, Jian Cao, and Bin Lin. 2021. CEO organizational identification and firm cash holdings. China Journal of Accounting Research 14: 183-205. [CrossRef]

Zouari, Sarra Ben Slama, and Neila Boulila Taktak. 2014. Ownership structure and financial performance in Islamic banks: Does bank ownership matter? International Journal of Islamic and Middle Eastern Finance and Management 7: 146-60. [CrossRef] 